\section{Two Decades of Change in Spanish Higher Education}

\section{José-Ginés Mora}

José-Ginés Mora is professor of economics at the University of Valencia. Address: Department of Applied Economics, Campus dels Tarongers, 46022, Valencia, Spain. E-mail: <ginesj@uv.es>.

$\mathrm{I}^{\mathrm{n}}$ $\mathrm{n}$ the last two decades, Spain has undergone profound social and economic changes that have greatly affected the higher education system. Continuous growth and structural reforms have defined the development of higher education in Spain.

\section{The 1983 Reforms}

The current structure of higher education was established by the 1983 University Reform Act, which greatly revised the legal framework of Spanish universities. Formerly completely controlled by the central government, universities have gained in autonomy and now depend more on regional governments. The legal reforms also democratized the internal structure of universities. Power was transferred from the state bureaucracy to university-level governing bodies, including nonacademic staff and students, that have decision-making powers in matters concerning the institution and departments and in electing the rector, deans, and department heads.

\section{Financial Resources}

The financial resources for universities have increased enormously in the last two decades, with total higher education expenditures in Spain reaching 1.1 percent of GDP in 1995. While this is still below the average in OECD countries, it is much higher than the figure for Spain just 10 years before $(0.54$ percent). It should be noted that unlike other European countries, Spanish universities have always charged tuition fees, which account for about 20 percent of the university budget.

\section{Legal reforms also democratized the in- ternal structure of universities.}

The increased financial resources and competitive modes of financing research have transformed research activities in Spanish universities. Since 1982, spending on research and development in universities has multiplied fourfold. Since 1986 the number of publications in the databases of the Institute of Scientific Information has more than tripled, and the country's share of scientific publications has gone from 1.3 to 2.4 percent.
Access

Generally speaking, access to higher education in Spain is quite open. New entrants to higher education comprise around 40 percent of the age cohort. Access is also fairly open to people of diverse socioeconomic backgrounds. Enrollments have multiplied threefold in the last two decades, and faculty and staff have grown at a similar pace. The rate of increase has declined in the last several years, and this year even showed a slight decrease due to the shrinking size of the age cohort.

\section{Accountability and Assessment}

Accountability and assessment are quite recent phenomena in Spanish universities but have developed rapidly in the last decade. Following several pilot projects, the $\mathrm{Na}$ tional Program for Assessment of Quality in Universities was established in 1995, with the goal of promoting quality and developing accountability, particularly on behalf of the program's main clients (students) and those responsible for finance (regional governments).

\section{New entrants to higher education com- prise around $\mathbf{4 0}$ percent of the age co- hort.}

\section{Some Perverse Effects}

In sum, the development of the Spanish higher education system in the last two decades could be judged as very positive. The main impetus for reform was the drive to modernize and democratize the universities, as well as adapt the higher education system to the socioeconomic needs of the country. However, universities are now entering a new period, one in which quality will be the most important challenge. Moreover, the reforms thus far have also generated some perverse effects, especially in the governing of universities. The excessive internal power of academics is impeding the ability of the system to respond quickly to external conditions and demands. It is generally agreed that legal and organizational changes will need to be introduced if universities are to meet the new challenges with success.

As in Burton Clark's well-known scenario, universities are currently moving from the sphere of influence of the state to that of the academic oligarchy. Introducing market forces will allow the higher education system to achieve an equilibrium in which the state (representing the whole community), academia (representing the experts in the production process), and the market (as the most effective mechanism to satisfy the needs of students and employers) are able to act in harmony. 
Key Areas

The introduction of market forces into Spanish higher education will require some structural changes, among which the following might be considered as key areas for attention.

\section{The introduction of market forces into Spanish higher education will require some structural changes.}

- The financial system. Some areas in need of reform are the system of allocating public funds-introducing performance-based financing; the capacity of institutions to control their own financial resources-allowing them to fix tuition fees and staff salaries; and an increase in the participation of the business community and students in the financing of universities.

- Diversification and mobility of staff and students. Although universities have taken timid steps toward diversification, the process needs to be stimulated. Universities should send signals to potantial clients (students and enterprises) informing them of the specific character of each institution. Currently, staff have the status of civil servants, and working conditions are similar at the various universities. Universities need mechanisms that would allow them to compete for the best staff. Student mobility and the option of selecting from among programs at different institutions, either Spanish or European, would be key factors in helping the university system to become more responsive to the market. An effective program for student aid would also greatly improve student mobility.

- University governance. The governing structure of universities has changed dramatically, which has introduced a high level of internal democracy into the institutions. This change has contributed to the renewal of higher education institutions. Nevertheless, approaches that were adequate for the reform and expansion of the system are less effective in the current situation, in which institutions have to compete for resources and for students and quality is the main goal. Experts on higher education generally agree on the need to alter the governing structures of universities to make them more entrepreneurial and managerial and thus better able to cope with the challenges of the future.

At present, these issues are being thoroughly discussed among politicians, university leaders, and experts. There is a general agreement that new initiatives must be introduced, and it is likely that major reforms will soon be implemented.

\section{Oxford University: Reflections of a Visiting Scholar}

\section{Xiangming Chen}

Xiangming Chen is professor in the Institute for Higher Education, Peking University, Beijing, China. Address: Institute of Higher Education, Peking University, Beijing 100871, China.

W henever I think about Oxford University, the image of the seven big trees standing at the northwest gate of University Park comes to mind. With their massive trunks and crumbling bark as well as surprisingly green leaves and upward-branching new growth, these trees appeared to me as a wonderful symbol of Oxford today: traditional and conservative, as well as modern and innovative.

Oxford is the oldest university in the English-speaking world, with a history of 800 years. With 39 colleges, over 150 departments and centers, 13,261 students, and 6,655 faculty and staff, the university serves as one of the world's leading institutions for teaching and research in higher education. During my six months there as a visiting scholar, I was often amazed by the interesting combination of a historical tradition of preserving the old and a desire to transform the institution to meet the needs of a changing society.

\section{For Oxonians, "tradition" seems to be the immediate response to anything dif- ficult.}

One example is Oxford's renowned college system. The colleges at Oxford are independent units with their own ruling bodies, decision-making power, financial resources, and academic disciplines. One at a time, the 39 colleges were established over the centuries with the support of the clergy, the community, and individual philanthropies. While providing the opportunity for close interpersonal communication, interdisciplinary exchange of ideas, and cheaper housing and food to its members, the college system has also tended to isolate the colleges from one another and create a disparity between the richer and the less wealthy colleges. College facilities-including libraries-are normally closed to nonmembers, preventing resources from being fully shared by the university as a whole. Although a fund has been established to help the poorer colleges, resistance from the more well endowed ones is still rather strong. Interestingly, whenever I asked why the existing colleges could not be reorganized accord- 